\title{
Spatial electromagnetic field intensity modelling of global system for mobile communication base stations in the Istanbul Technical University Ayazaga campus area
}

\author{
Kubra Boz, ${ }^{1}$ Hayri Hakan Denli ${ }^{2}$ \\ ${ }^{1}$ Institute of Geographic Information Technology; ${ }^{2}$ Faculty of Civil Engineering, Istanbul Technical \\ Univesity (ITU), Ayazaga Campus, Sariyer/Istanbul, Turkey
}

\begin{abstract}
The rapid development of the global system for mobile communication services and the consequent increased electromagnetic field (EMF) exposure to the human body have generated debate on the potential danger with respect to human health. The many research studies focused on this subject have, however, not provided any certain evidence about harmful consequences due to mobile communication systems. On the other hand, there are still views suggesting such exposure might affect the human body in different ways. To reduce such effects to a minimum, the International Commission on Non-Ionizing Radiation Protection (ICNIRP) has declared boundary values for the energy released by the base stations, which are the main source of the electromagnetic
\end{abstract}

Correspondence: Kubra Boz, Istanbul Technical Univesity (ITU), Institute of Geographic Information Technology, Ayazaga Campus, Sariyer/ Istanbul, Turkey.

Tel.: +1.979.7030302.

E-mail: k.bilginol@gmail.com

Key words: Electromagnetic field intensity; EMF Health effects; Geostatistical interpolations; Spatial modelling; Base stations; Turkey.

Acknowledgments: the authors would like to thank for the support given by ITU/Scientific Research Projects (Bilimsel Arastırma Projeleri).

Contributions: the authors contributed equally.

Conflict of interest: the authors declare no potential conflict of interest.

Funding: None.

Received for publication: 31 October 2016

Revision received: 30 June 2017.

Accepted for publication: 30 June 2017.

(C) Copyright K. Boz et al., 2018

Licensee PAGEPress, Italy

Geospatial Health 2018; 13:527

doi:10.4081/gh.2018.527

This article is distributed under the terms of the Creative Commons Attribution Noncommercial License (CC BY-NC 4.0) which permits any noncommercial use, distribution, and reproduction in any medium, provided the original author(s) and source are credited. fields. These values are accepted by many countries in various parts of the world. The aim of this study was to create EMF intensity maps for the area covered by Istanbul Technical University (ITU) and find areas of potential risk with regard to health considering the current situation and future trends. In this study, the field intensities of electromagnetic signals issued at the frequencies of 900 and $1800 \mathrm{MHz}$ were measured in V/m at 29 pre-specified survey points using a spectrum analyzer (Spectran HF-6065). Geographic information systems and spatial interpolation techniques were used to produce EMF intensity maps. Three different spatial interpolation methods, minimum mean square error, Radial Basis and Empirical Bayesian Kriging, were compared. The results were geographically analyzed and the measurements expressed as heat maps covering the study area. Using these maps, the values measured were compared with the EMF intensity standards issued by ICNIRP. The results showed that the exposure levels to the EMF intensities were all within the ICNIRP limits at the ITU study area. However, since the EMF intensity level with respect to human health is not known, it is not possible to confirm if these levels are safe or not.

\section{Introduction}

The usage of wireless networks and mobile communication are increasing daily and it is important to know if current or increasing electromagnetic field (EMF) intensities are harmful for human health. The electromagnetic signals involved are waves with particular frequency and amplitude that may emerge from natural sources as much as from man-made technologies, such as the global system for mobile communication (GSM) services and Wi-Fi networks. There is a strong correlation between usage of wireless communication technologies and the strength of the EMF (WHO, 2016) and this is more evident in certain areas (Hayland, 2000). As a result, it is inevitable to be exposed to EMF. While radio frequency waves emitted by mobile phones particularly affect the head, waves emitted by the base stations have an impact on the entire body.

Since the 1990s, the development of GSM technologies generate a significant increase on imposed EMF varieties and sources. In Turkey, new technical GSM infrastructures have recently been established with $2 \mathrm{G}$ and $3 \mathrm{G}$ approaches being replaced with $4.5 \mathrm{G}$ technology (BTK, 2015). As a result of the EMF increase due to the continuing development of GSM systems, the effect of these technologies on human health is currently extensively debated (Özgüner and Mollaoğlu, 2006). The 
International Commission on Non-Ionizing Radiation Protection (ICNIRP) has defined limit values for electromagnetic radiation from the base stations intended to minimize potential health effects, particularly aiming at the protection of biological tissues from thermal effects (ICNIRP, 1998). Many countries have adopted these limit values as standards. The many existing research studies focused on this subject have, however, not provided any certain results. For example, Koivisto et al. (2000) found that EMFs have a measurable effect on human cognitive performance and brain function, while Schüz et al. (2008) report that there is some evidence for an association between radio frequency fields and childhood leukaemia, and Agarwal et al. (2011) have shown evidence that electromagnetic waves can kill neurons, absorb proteins and cause general stress in the human body. On the other hand, many others have found no significant effects between electromagnetic exposure and human health, e.g., Finnie et al., (2006) and Kim et al. (2008).

Despite the absence of clear results with regard to EMFs and human health, it is important to analyze the intensity values, particularly in areas where high levels can be expected. University campuses, which are generally populated by many active students and instructors, represent such high-risk areas. The Ayazaga campus of the Istanbul Technical University (ITU) was therefore selected as study area measuring EMF intensities at 900 and 1800 $\mathrm{MHz}$ frequencies. Our aim was to produce EMF intensity maps (heat maps) to be used for analysis and definition of the relationship between high populations and high EMF intensities.

\section{Basic electromagnetic field information}

EMFs are used in so many ways and so many areas that it can be said that it is constantly all around us, e.g., in the form of street and road illumination, telecommunication, remote sensing, defence industry technologies, etc. Its overall intensity increases in parallel with new developments (Sevgi, 2004). A wave has various features: the period is the time it takes to complete a cycle of upward and downward movement and the frequency is the number of such cycles completed in a second. The distance the wave travels during one period is the wavelength, which is the distance between the sequenced peeks. Wave height is the distance from start position to peak position of the wave. This distance changes in terms of the amount of energy. Its unit is decibel (db). Frequency can be described as the number of waves passing a constant point, i.e. the number of amplitude intervals (or cycles) in a second. Its unit is Hertz $(\mathrm{Hz})$. An electric field is generated by pull and push force on electrical loads. A magnetic field is generated when electric charge carriers, such as electrons, move through space or within an electrical conductor (NASA, 2015). An electromagnetic wave consists of two orthogonal electric and magnetic fields, which must be analyzed separately. An electromagnetic spectrum is defined as the combination of all the different wavelengths of electromagnetic radiation, including radio waves, visible light and X-rays (Bakshi and Godse 2009).

\section{Field intensities and standards}

There are two types of standards with regard to human health, fundamental and derivative, and they have been defined by ICNIRP. If absorption of electromagnetic energy increases body warmth by $1{ }^{\circ} \mathrm{C}$ in a normal-sized human, it is assumed harmful and thus specifies a fundamental limit. It corresponds to a maximum value of tissue absorption per $\mathrm{kg}$ of $4 \mathrm{~W}$ according to research carried out by ICNIRP. The specific absorption rate (SAR) is defined as 10 times the maximum value of tissue absorption rate for business areas and 50 times that value for general and settlement areas (ICNIRP, 1998), i.e.: i) Business areas (Factories, plazas etc.): $0.4 \mathrm{~W} / \mathrm{kg}$ SAR; ii) General and settlement areas: 0.08 $\mathrm{W} / \mathrm{kg}$ SAR.

In order to determine the SAR, the EMF intensity in the tissue must be measured. International scientific research committees, such as the Institute of Electrical and Electronics Engineers (IEEE), do these studies and they use a modelling approach (Akleman and Sevgi, 1998).

The fundamental limits given by ICNIRP concerns the intensity absorbed by the tissues. The electromagnetic power density limits are defined per $\mathrm{m}^{2}$ and its unit is $\mathrm{W} / \mathrm{m}^{2}$. According to the opinion expressed by ICNIRP, it would be enough to define the limits in terms of its thermal effect. However, the limits, and how they are defined, are the main source of dispute and there may be differences in this respect between countries and also between international institutions. The accepted limit value according to ICNIRP is $42 \mathrm{~V} / \mathrm{m}\left(4.5 \mathrm{~W} / \mathrm{m}^{2}\right)$ at $900 \mathrm{MHz}$ and $59 \mathrm{~V} / \mathrm{m}\left(9 \mathrm{~W} / \mathrm{m}^{2}\right)$ at $1800 \mathrm{MHz}$. These values are accepted by Turkey, USA and most countries of the European Union but Italy, France (Paris), Lithuania and Poland accept smaller limit values than ICNIRP for $900 \mathrm{MHz}$ (Gilberti et al., 2009; ITU, 2012; GSMA, 2014).

The limit values on ICNIRP guide are defined by the results of research on short- and medium-term burning, shock and heat effects on experimental objects. Long-term effects, such as cancerogenic facts are not used for defining limit values because of lacking scientific data. Therefore long-term effects are ignored in the guide (Sevgi, 2000) (Table 1).

Table 1. Limits for electric field intensities for Turkey and selected countries of the European Union.

\begin{tabular}{|c|c|c|}
\hline Country & $900 \mathrm{MHz}$ Electric Field Intensity (V/m) & $1800 \mathrm{MHz}$ Electric Field Intensity (V/m) \\
\hline Italy & 6 & \\
\hline Lithuania & 6.1 & \\
\hline Poland & 7 & \\
\hline France (only in Paris) & 5 & 7 \\
\hline Turkey & 41.25 & 58.34 \\
\hline
\end{tabular}

Values based on GSMA, 2014 


\section{Base stations}

In the field of telecommunication, the base station is the electromagnetic source. The antennas on the base stations transform electric signals to electromagnetic waves. The basic characteristics of antennas can be unidirectional or omnidirectional (European Commission, 2010) (Figure 1).

GSM operators use base stations for connecting communications issued by hand units (the telephones). The antenna on the base station is a crucial part of the system. To allow the waves to travel far, the location of the antenna must be in a high position, i.e. mounted on tall buildings or towers. However, it may also be mounted on building walls or indoors and would then often have less output power. In order to gain output power density, the antenna is often directed both horizontal and vertical. Thus, it will radiate in a sector since there is no reason to transmit power straight up in the air or in directions where no receivers are (Hamnerius and Uddmar 2016).

The base stations are generally placed on top of a tower 10-30 meters high and the antennas have $5-6^{\circ}$ beam that touches the ground at a minimum of $50 \mathrm{~m}$ away from the tower. The EMF intensity, expressed in volts per meter $(\mathrm{V} / \mathrm{m})$, issued from a $60 \mathrm{~W}-$ base station on a $10 \mathrm{~m}$ high tower would be very low $\mathrm{V} / \mathrm{m}$ (please explain this unit) outside of the $50 \mathrm{~m}$ radius. However, wrongly placed base stations can exceed the limit values recognized in the standards of ICNIRP or other local institutions (Sevgi, 2000).

\section{Materials and Methods}

\section{Study area}

The Ayazaga campus of ITU was selected for the experimental work described here. ITU is one of the biggest universities in Istanbul and has 32,307 students and 1443 academic staff (ITU, 2016.). The campus area has nine base stations and 29 survey points were established in relatively close connection with these (Figure 2). The area comprises approximately $3 \mathrm{~km}^{2}$ and includes four technical centres, one small to medium industry development organization (KOSGEB) laboratory, one kindergarten, one elementary school and one high school. Because of these facilities, ITU has a high daytime general population in addition to students and academic staff and is categorized as a sensitive area due to the congregation of many potentially vulnerable people. The measurements of EMF intensities generated by the base stations were compared with the limit values of Italy in this study.

\section{Measurement techniques}

In the study, a Spectran HF-6065 portable RF spectrum analyser (Aaronia, Seneca, SC, USA) was used for the measurements. This instrument is equipped both with logarithmic and rod antennas. The former is used for directional measurements, where the antenna is moved to find the direction of the electromagnetic radiation, while the rod antenna measures the electromagnetic field intensity independent of direction. In this study, only the rod antenna was used.

The spectrum analyser used measures frequency bands between $10 \mathrm{MHz}$ and $6 \mathrm{GHz}$ and has a sampling precision up to 60 $\mathrm{dB}$. It presents measurement results as frequency-time charts on its screen and the signal can also be transferred to computers equipped with a USB port. As a result, it is possible to make detailed measurements and analyses (Aaronia, 2016). In a first step of the measurement of EMF intensities, the locations of the source base stations in the study area were recorded. Then, the effect areas of base stations with $50 \mathrm{~m}$ and $300 \mathrm{~m}$ radii were established using ArcGIS software (ESRI, Redlands, CA, USA). In a second step, the 29 different survey locations were set up within the $300 \mathrm{~m}$ effect areas (Figure 1). In a final step, the EMF intensities were measured for 15 minutes at every survey point. Measurements were made by establishing constant set-up at the measurement locations with the Spectran ${ }^{\circledR}$ HF-6065 apparatus, a computer and the Spectrum Analyser software.

\section{Spatial statistics}

Estimation of values at unmeasured locations can be carried out using values of neighbouring measured locations and spatial statistical interpolation techniques to create a surface that covers both measured and estimated points. This is intended to represent best empirical reality. However, different spatial interpolation methods can result in different estimates and thus the surfaces created vary slightly (Legendre and Legendre, 1998), so the selected
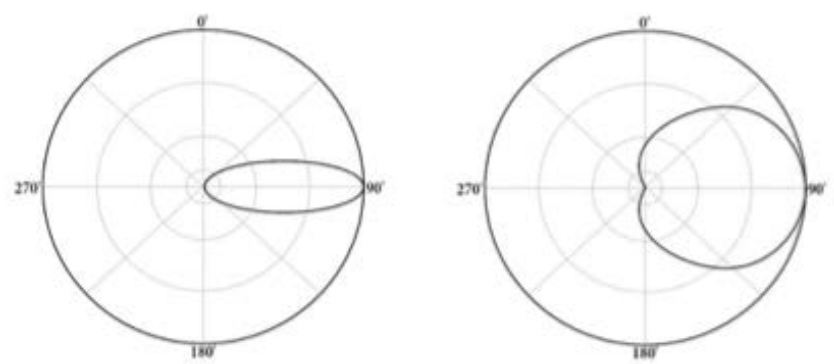

Figure 1. Directional and omnidirectional antennas. Directional antennas receive signals in a specified direction. Omnidirectional antennas receive signals over a large area in many directions as shown in the right side of the Figure. (European Commission, 2010).

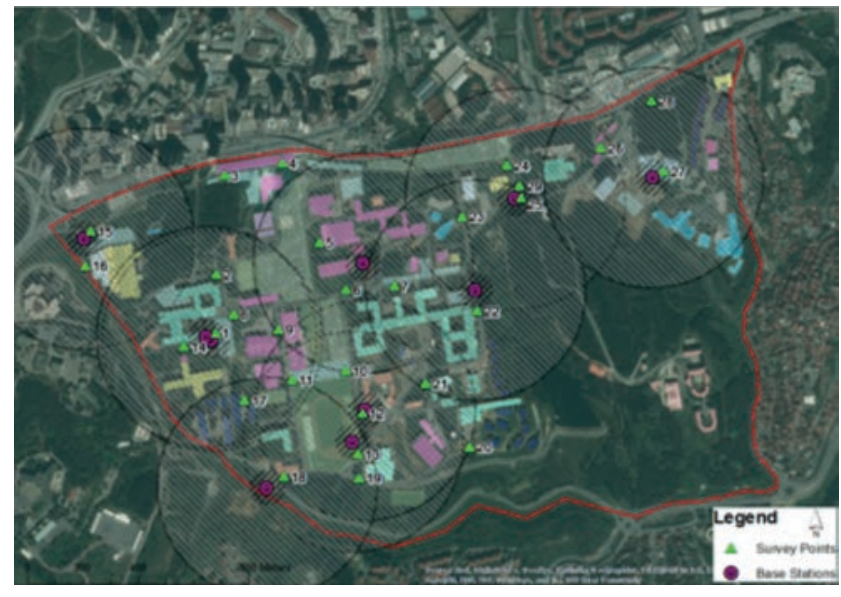

Figure 2. Project area, base stations and survey point. 
interpolation method must be evaluated accurately. There are two main types of interpolation methods: deterministic and stochastic. The latter provides an assessment of prediction errors with estimated variances, while the former does not. Basically radial basis (RB), inverse distance weighting (IDW) and polynomial are deterministic interpolation methods, while regression techniques and Kriging are stochastic methods (Li and Heap, 2008). The RB completely regularized spline and Empirical Bayesian Kriging (EBK) spatial statistical interpolation methods can be used for mapping. The RB and spline functions can simply be determined as a weighted linear function of distance from grid point to data point without smoothing and bias factor (Goodchild, 2015). Kriging is a probabilistic predictor.

In this study, all three different spatial interpolation methods, i.e. IDW, RB and EBK, were used and the results compared. The goal was to find the method creating the best representation of reality for the measured EMF intensity. Twenty-nine different survey points were used for measurement of EMF intensity values at 900 $\mathrm{MHz}$ and $1800 \mathrm{MHz}$ frequencies creating two signal maps, one for each frequency. Applying the ArcGIS software to the RB Basis completely regularized spline method we created the heat-map for frequencies around $1800 \mathrm{MHz}$ and the EBK method for the 900 $\mathrm{MHz}$ frequencies. Bayes' theorem was used according to Krivoruchko (2012).

\section{Results}

The results for RB completely regularized spline method and the EBK are given in Table 2. The outcome of measuring the EMF intensities between $850 \mathrm{MHz}$ and $1900 \mathrm{MHz}$ at each survey point in the study area are shown in Table 3 using the same codes as in Figure 2. At the $900 \mathrm{MHz}$ frequency, the highest values were measured at survey point $14(2.7 \mathrm{~V} / \mathrm{m})$ and survey point $15(1.6 \mathrm{~V} / \mathrm{m})$, while the highest values at $1800 \mathrm{MHz}$ were found at survey points $16(2.89 \mathrm{~V} / \mathrm{m})$ and $29(5.5 \mathrm{~V} / \mathrm{m})$.

Survey point 14 was located in front of the Civil Engineering building. This point was covered by two different base stations with a $300 \mathrm{~m}$ radius effect area (Figures 2 and 3). Survey point 15 was in the area of $1^{\text {st }}$ Technical Centre close to the north-western corner of the campus (Figure 4 ). This point was in the $50 \mathrm{~m}$ radius effect area of the base station and there are high-density business areas north of this point. For this reason, this point can also be affected by base stations outside the study area.

Survey point 16 was inside the area of $1^{\text {st }}$ Technical Centre within the 50m-effect area of the base station (Figure 5) and survey point 29 was located across Istinye Park, which is one of the most popular shopping malls in Istanbul. The survey point was within the 50m-effect area of the base station (Figure 6).

Table 2. Spatial interpolation errors at electromagnetic field intensity (EFI) measurements.

\begin{tabular}{|c|c|c|c|c|c|c|}
\hline \multirow{2}{*}{ EFI spatial interpolation error } & \multicolumn{3}{|c|}{$1800 \mathrm{MHz}$} & \multicolumn{3}{|c|}{$900 \mathrm{MHz}$} \\
\hline & IDW* & EBK** & $\mathbf{R B}_{\mathrm{crs}} * * *$ & IDW* & EBK** & $\mathbf{R B}_{\mathrm{crs}} * * *$ \\
\hline Survey point count & 29 & 29 & 29 & 29 & 29 & 29 \\
\hline Minimum & $-3.7 \mathrm{~V} / \mathrm{m}$ & $-4.48 \mathrm{~V} / \mathrm{m}$ & $-3.92 \mathrm{~V} / \mathrm{m}$ & $-2.04 \mathrm{~V} / \mathrm{m}$ & $-1.7 \mathrm{~V} / \mathrm{m}$ & $-1.83 \mathrm{~V} / \mathrm{m}$ \\
\hline Maximum & $3.09 \mathrm{~V} / \mathrm{m}$ & $1.33 \mathrm{~V} / \mathrm{m}$ & $1.59 \mathrm{~V} / \mathrm{m}$ & $0.94 \mathrm{~V} / \mathrm{m}$ & $0.75 \mathrm{~V} / \mathrm{m}$ & $0.75 \mathrm{~V} / \mathrm{m}$ \\
\hline Standard deviation & $1.08 \mathrm{~V} / \mathrm{m}$ & $1.02 \mathrm{~V} / \mathrm{m}$ & $0.94 \mathrm{~V} / \mathrm{m}$ & $0.66 \mathrm{~V} / \mathrm{m}$ & $0.62 \mathrm{~V} / \mathrm{m}$ & $0.64 \mathrm{~V} / \mathrm{m}$ \\
\hline Mean error & $0.2 \mathrm{~V} / \mathrm{m}$ & $0.03 \mathrm{~V} / \mathrm{m}$ & $0.08 \mathrm{~V} / \mathrm{m}$ & $-0.02 \mathrm{~V} / \mathrm{m}$ & $-0.01 \mathrm{~V} / \mathrm{m}$ & $-0.02 \mathrm{~V} / \mathrm{m}$ \\
\hline Mean square error & $1.24 \mathrm{~V} / \mathrm{m}$ & $1.05 \mathrm{~V} / \mathrm{m}$ & $0.9 \mathrm{~V} / \mathrm{m}$ & $0.43 \mathrm{~V} / \mathrm{m}$ & $0.39 \mathrm{~V} / \mathrm{m}$ & $0.42 \mathrm{~V} / \mathrm{m}$ \\
\hline
\end{tabular}

*Inverse distance weighting; ${ }^{* *}$ Empirical Bayesian Kriging; ***Radial basis (completely regularized spline).

Table 3. The electromagnetic field intensities at the various survey points.

\begin{tabular}{|c|c|c|c|c|c|}
\hline \multirow[t]{2}{*}{ Survey point code } & \multicolumn{2}{|c|}{ Maximum power (V/m) } & \multirow[t]{2}{*}{ Survey point code } & \multicolumn{2}{|c|}{ Maximum power (V/m) } \\
\hline & $900 \mathrm{MHz}$ & $1800 \mathrm{MHz}$ & & $900 \mathrm{MHz}$ & $1800 \mathrm{MHz}$ \\
\hline 1 & 1.015 & 0.792 & 15 & 1.665 & 0.406 \\
\hline 2 & 0.063 & 0.061 & 16 & 0.924 & 2.895 \\
\hline 3 & 0.235 & 0.17 & 17 & 0.192 & 0.151 \\
\hline 4 & 0.186 & 0.148 & 18 & 0.409 & 0.057 \\
\hline 5 & 0.165 & 0.406 & 19 & 0.314 & 1.396 \\
\hline 6 & 0.299 & 0.325 & 20 & 0.041 & 0.111 \\
\hline 7 & 0.166 & 0.408 & 21 & 0.256 & 1.856 \\
\hline 8 & 0.303 & 0.326 & 22 & 1.622 & 1.324 \\
\hline 9 & 0.043 & 0.133 & 23 & 0.437 & 0.102 \\
\hline 10 & 0.230 & 0.283 & 24 & 0.035 & 2.045 \\
\hline 11 & 0.372 & 0.173 & 25 & 0.03 & 1.845 \\
\hline 12 & 1.543 & 0.731 & 26 & 0.044 & 0.099 \\
\hline 13 & 0.231 & 1.323 & 27 & 0.198 & 0.069 \\
\hline \multirow[t]{2}{*}{14} & 2.723 & 0.484 & 28 & 0.950 & 0.500 \\
\hline & & & 29 & 0.095 & 5.500 \\
\hline
\end{tabular}


The distribution of EMF intensity values at $900 \mathrm{MHz}$ is shown on a map created by application of the EBK interpolation method using the ArcGIS software (Figure 7). As can be seen, the EMF intensity values to the East and in the south-eastern areas are higher than in other parts of the map. The map for $1800 \mathrm{MHz}$ was cre- ated by using RB (completely regularized spline) interpolation method with the ArcGIS software. Here, the highest EMF intensities were also found to the East but also in the north-eastern areas (Figure 8). These two maps show that there are no higher EFI values than limit values which are defined by ICNIRP. But study area
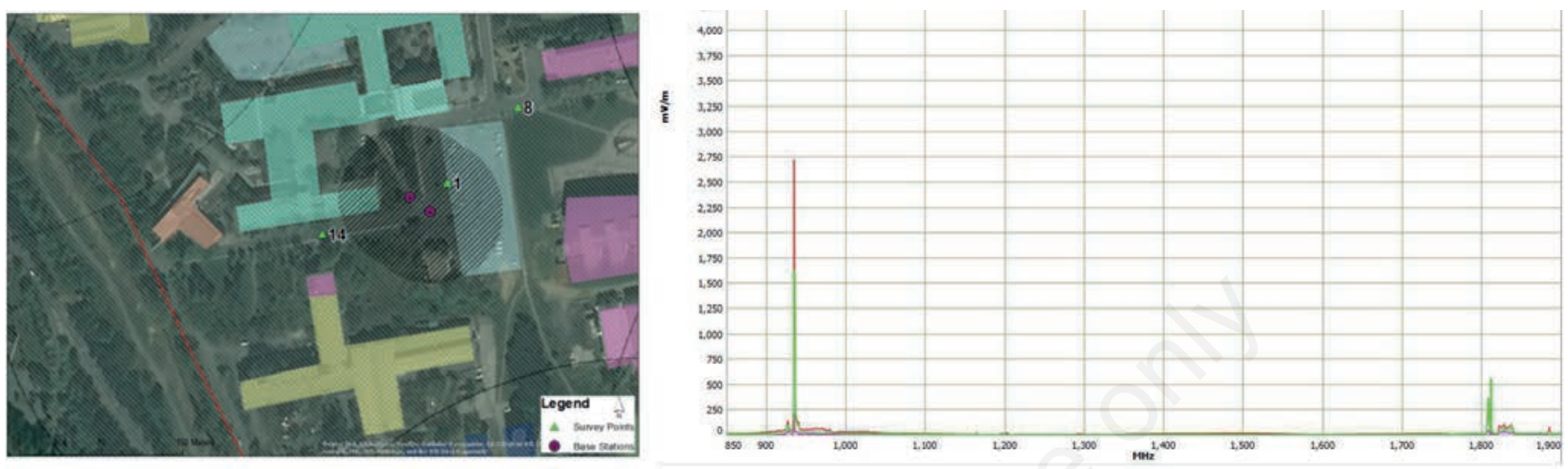

Figure 3. Location of survey point 14 and the graph of measured values between 850 and $1900 \mathrm{MHz}$ at this point.
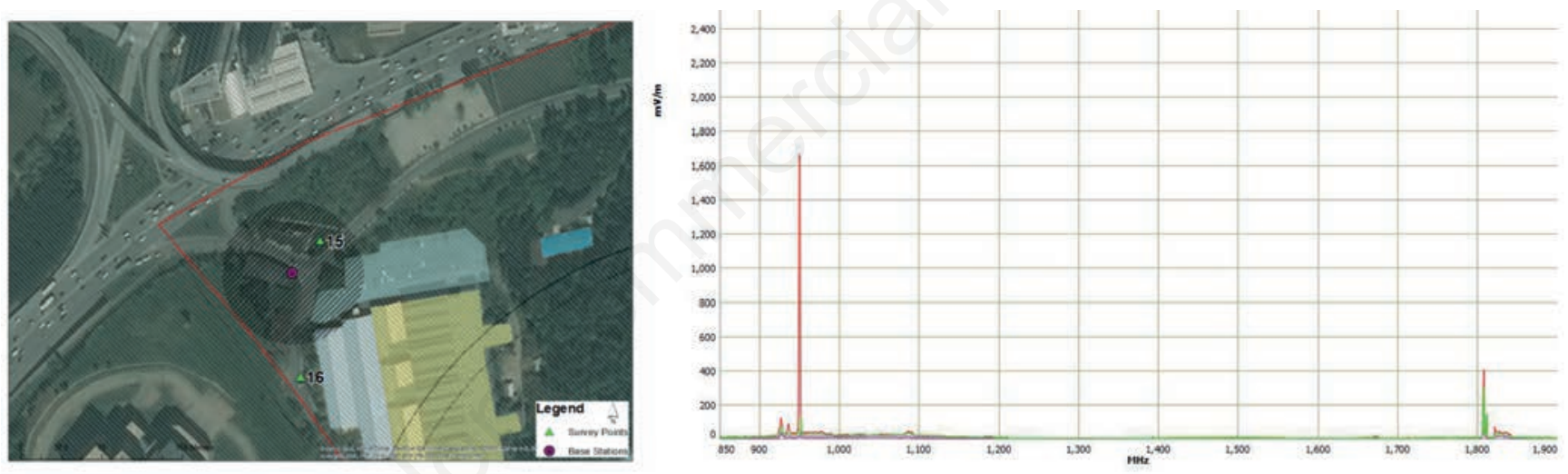

Figure 4. Location of survey point 15 and the graph of measured values between 850 and $1900 \mathrm{MHz}$ at this point.
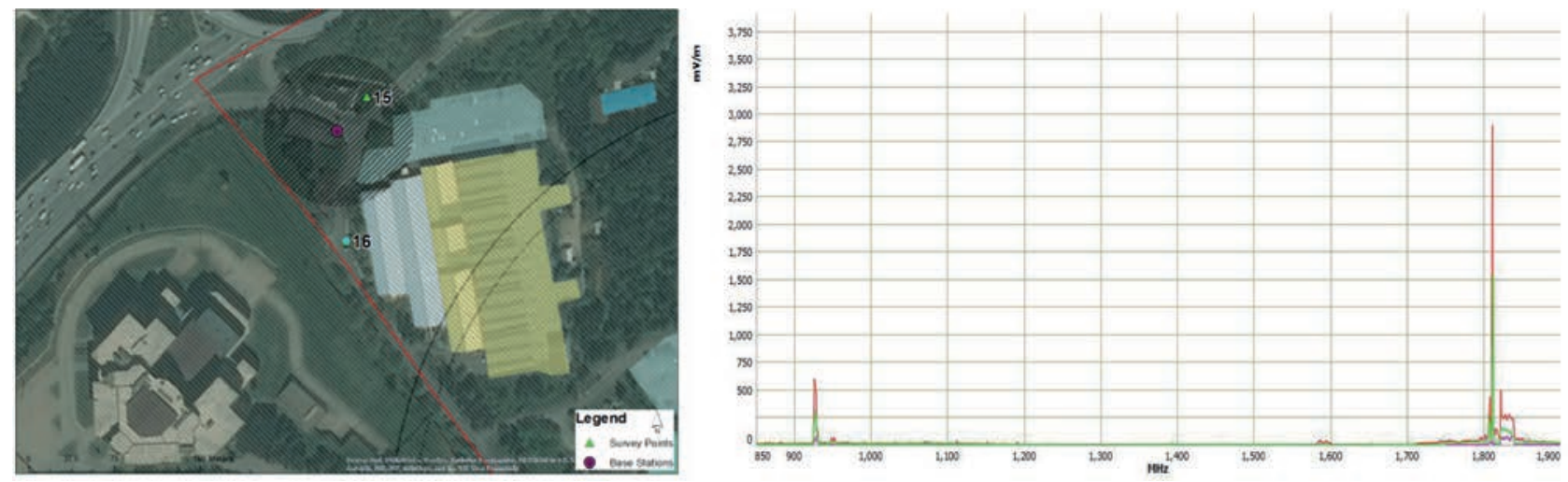

Figure 5. Location of survey point 16 and the graph of measured values between 850 and $1900 \mathrm{MHz}$ at this point. 
must be considered as sensitive area which should has special limits. In contrary, the values that measured on $900 \mathrm{MHz}$ lower than the values that measured $1800 \mathrm{MHz}$. in the study area because $3 \mathrm{G}$, 4G and LTE technologies use 1700-1900 MHz frequency band and the usage of this technologies increasing day by day.

\section{Discussion and Conclusions}

Analyzing the maps showing the distribution of EMF intensity in the ITU area, we found all values to be $\leq 5.5 \mathrm{~V} / \mathrm{m}$, i.e. under the limits determined by ICNIRP and also accepted by Turkey.

However, the accepted limit values differ from country to country. In this point, the limits accepted for sensitive areas like universities is $6 \mathrm{~V} / \mathrm{m}$ in Italy. Considering the EMF intensity values of the north-western area of ITU are very near the Italian limits. The effects of electromagnetic radiation on human health are still a research subject and there are no certain results yet. Since there may well be more unknown such effects than known ones, precautions must be taken and prevention from exposure to EMF be effectuated as much as is possible. In sensible areas like schools, hospitals, the EMF intensity values should be regularly be measured with relatively short periods between, so that limit values are not surpassed. To protect human health, accepted limit values must also be reconsidered and updated whenever new research findings are made available.

There are many unknown issues about human health in connection with EMF and harmful possibilities should always be under consideration as the accepted limit values in Turkey are relatively high. The ITU campus area, in particular, has high EMF intensity values compared to the more sensible area limits of Italy. In addition, signal transmitters in EMF-affected areas should be as far as possible located away from $300 \mathrm{~m}$ radius effect area of base stations in sensitive areas.

This study was modelled on the EMF intensity distribution of the ITU Ayazaga campus area, but it can easily be applied to all universities campus areas. Importantly, EMF intensity values which are not generated by base stations should also be measured, mapped and controlled with limit values indoors and outdoors.
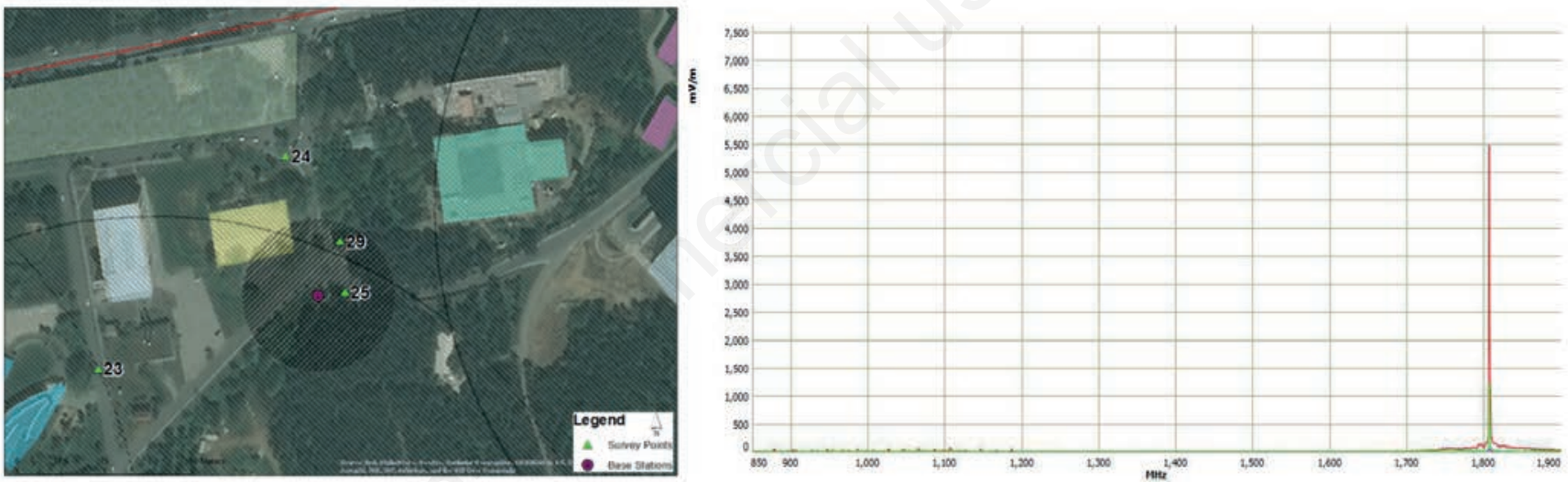

Figure 6. Location of survey point 29 and the graph of measured values between 850 and $1900 \mathrm{MHz}$ at this point.

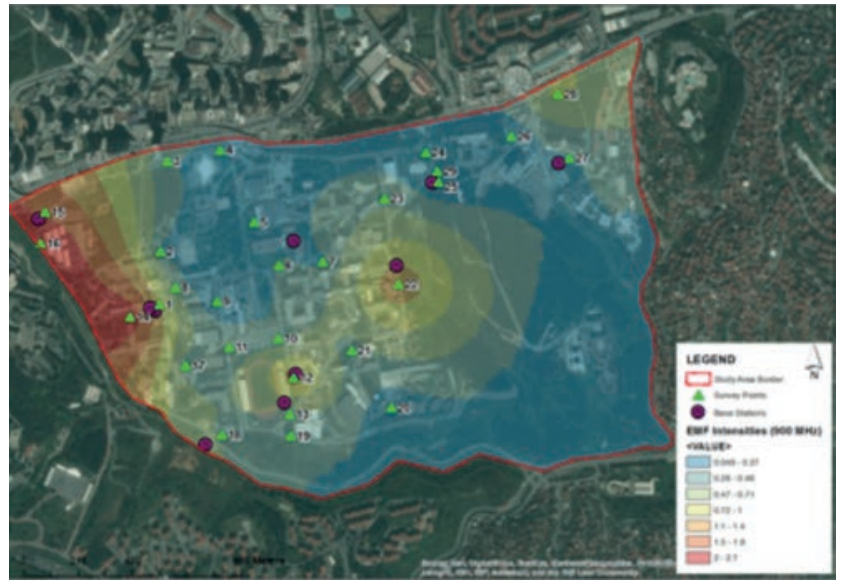

Figure 7.900 MHz electromagnetic field intensity distribution map.

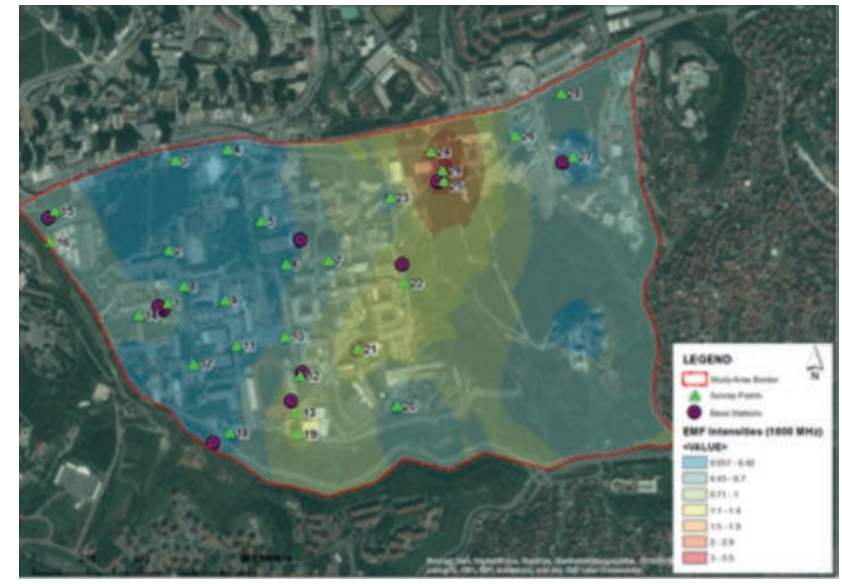

Figure 8. $1800 \mathrm{MHz}$ electromagnetic field intensity distribution map. 
ITU, Sayılarla Istanbul Teknik Üniversitesi (Istanbul Technical University with Numbers), Available from: http://sayilarla. itu.edu.tr/\#s9. Accessed: June 2016.

Aaronia, Spectran ${ }^{\circledR}$ HF-6065 RF Spectrum Analyzer Manual. Available from: http://www.aaronia.de/Datanblaetter/Messgeraete/ Spectrum_Analyzer_Spectran_HF-6000-Serie.pdf. Accessed: June 2016.

Agarwal A, Gupta A, 2011. Effect of electromagnetic radiations on humans: a study. In: Proceedings of the IEEE Students' Technology Symposium, pp 75-80. Available from: http://www.ieee.org/conferences_events/conferences/conferencedetails/index.html?Conf_ID=18009.

Akleman F, Sevgi L, 1998. FDTD analysis of human head: mobile phone interaction in terms of specific absorption rate (SAR) calculations and antenna design. In: Proceedings of IEEE-APS Conference on Antennas \& Propagation for Wireless Communication. pp 55-85.

Bakshi UA, Godse AP, 2009. Basic Electronics Engineering. Pune, India: Technical Publications. pp 8-10.

BTK, The tender of $4.5 \mathrm{G}$ was approved (4.5G İhalesi Onayland1) 2015. Available from: https://www.btk.gov.tr/tr-TR/ Kurumdan-Haberler/BTK-45G-Ihalesini-Onayladi. Accessed: July 2016.

European Commission, 2010. Electromagnetic Fields Report, Special Eurobarometer 347/Wave 73.3, TNS Opinion\&Social.

Finnie JW, Blumbergs PC, Manavis J, Kuchel TR, 2006. Effect of mobile telephony on blood-brain barrier permeability in the fetal mouse brain. Pathology 38:231-3.

Hamnerius Y, Uddmar T, Microwave exposure from mobile phones and base stations in Sweden. Available from: https://www.land-sbg.gv.at/celltower. Accessed: June 2016.

Hyland GJ, 2000. Physics and biology of mobile telephony. Lancet 356:1833-6.

ICNIRP, 1998. Guidelines for limiting exposure to time-varying electric, magnetic and electromagnetic fields (up to $300 \mathrm{GHz}$ ). Health Phys 74:494-522.

Kim TH, Huang TQ, Jang JJ, Kim MH, Kim HJ, Lee JS, 2008. Local exposure of $849 \mathrm{MHz}$ and $1763 \mathrm{MHz}$ radiofrequency radiation to mouse heads does not induce cell death or cell proliferation in brain. Exp Mol Med 40:294-303.

Koivisto M, Krause CM, Revonsuo A, Laine M, Hämäläinen H, 2000. The effects of electromagnetic field emitted by GSM phones on working memory. Cogn Neurosci Neuroreport 11:1641-3.

NASA, 2015. Imagine the Universe! Dictionary. Available from: https://imagine.gsfc.nasa.gov/resources/dictionary.html

Li J, Heap AD, 2008. A review of spatial interpolation methods for environmental scientists. Canberra, Australia: Geoscience Australia, $127 \mathrm{pp}$.

Özgüner F, Mollaoğlu H, 2006. Biological effects on the organism's magnetic field (Manyetik alanin organizma üzerindeki biyolojik etkileri), S.D.Ü. Tıp Fakültesi Dergisi.

Schüz J, Ahlbom A, 2008. Exposure to electromagnetic fields and the risk of childhoodleukaemia: a review. Radiat Prot Dosimetry 132:202-11.

Sevgi L, 2000. Electromagnetic pollution, cell phones and base stations (Kirlilik, Cep Telefonları ve Baz İstasyonları), EMO İstanbul Şube Bülteni, pp 21-26.

Sevgi L, 2004. Haberleşme sistemleri ve elektomagnetik dalga yayılımı (Communication systems and electormagnetic wave distribution), Endüstri-Otomasyon Dergisi.

Turkey Ministry of Enviroment (TC. Çevre Bakanlığg1), 2000. Environmental pollution prevention and control headquarters circular (Çevre Kirliliğini Önleme ve Kontrol Genel Müdürlüğü Genelgesi), B.19.0.ÇKÖ.0.02.00.03, Official Gazette Gazete, Vol. 24130.

WHO, Electromagnetic fields (EMF)/About electromagnetic fields. Available from: http://www.who.int/peh-emf/about/ WhatisEMF/en/. Accessed: June 2016. 